\title{
Stella Martini y María Eugenia Contursi (compiladoras). Comunicación pública del crimen y gestión del control social.
}

Buenos Aires: La Crujía, 2012. 286 p. ISBN 978-987-601-183-9

Este libro, pensado y diseñado colectivamente, cuenta con una decena de artículos cuyos tópicos se relacionan con los efectos, las causas y las consecuencias de los fenómenos comunicacionales y la gestión del control social por parte de ciertas instituciones y prácticas profesionales concretas. El grupo de investigadores de la Universidad de Buenos Aires analiza esos fenómenos y abre líneas de observación de múltiples reflexiones.

Partiendo de la base de que el control social se exige cuando las instituciones no lo garantizan o emergen problemáticas relacionadas con la seguridad, la noticia policial reiterada con énfasis se ofrece como el formato discursivo más idóneo para hacer más natural el reclamo y masificarlo. La noticia sobre el delito, tradicionalmente moralista, suma a la apelación la indignación ciudadana y es así como articulando dimensiones del área de la legalidad y de lo profano cobra una legitimación que trasciende a las denuncias y las exigencias por mayor control y políticas represivas para controlar el fenómeno. Esta mediación -en relación con otras variables de importancia, como el rol de la justicia, el accionar represor y de otras instituciones- justifica la marca fundacional de la prensa moderna: el testimonio.

En la primera parte de la obra "Opinión pública, medios masivos y control social. ¿Los bárbaros están entre nosotros?”, Stella
Martini aborda el campo de la comunicación pública, los espacios, las agencias, ya actores que exceden el marco de los medios masivos y de las instituciones, problematizando sus fronteras e indagando en los modos discursivos que hacen a su complejidad y su ambigüedad. Pone énfasis en el sensacionalismo, recurso característico en el relato sobre el delito en la vida cotidiana, entendiendo que las agencias de mano dura, las políticas, las organizaciones sociales y los medios masivos en general recurren al conflicto para desterrar las políticas de inclusión y la equidad social e implicar negativamente la capacidad de gobernabilidad en la actualidad.

Por otra parte, los discursos sobre las infracciones, los delitos, las penas, las leyes y las relaciones consecuentemente implicadas en las prácticas institucionales y sociales tienen en los medios, por su mismo alcance y masividad, el soporte y el canal con mayor posibilidad de eficacia comunicacional. Difícil es abordar los planos discursivos del individuo y la opinión pública separándolos de los medios informativos, teniendo en cuenta que las agendas de prensa informativa gozan de una fuerte legitimidad que opera de modo reflexivo, toda vez que el mismo sentido común elaborado por la noticia policial coincide $y$ reactualiza las voces de vastos sectores de la población. 
Según sus autores "el análisis comunicacional y cultural" es la herramienta analítica fundamental para un acercamiento a esta problemática porque permite dar cuenta de la densidad de las formas de construcción del sentido que agentes y agencias realizan y difunden sobre delitos, infracciones, leyes, penas, usos y apropiaciones del espacio público, de la privacidad, de las actuaciones, del control y del orden social. Es un estudio de las mediaciones donde se encuentran los cruces y los actores, las miradas oblicuas y las interpretaciones posibles de un conjunto problemático en el que el control social es un tópico consecuente del sentido común y que atraviesa toda la obra.

El libro presenta varios casos de estudio en que los polos de la comunicación política se cruzan y entreveran necesariamente: los medios masivos, la sociedad y los diferentes actores institucionales. Las técnicas metodológicas de abordaje de dichos casos son también heterogéneas: articulando métodos cualitativos y cuantitativos se ha recurrido al trabajo etnográfico, usando técnicas de observación no participantes y entrevistas para la obtención de datos en diversos barrios e instituciones de seguridad. El relevamiento de un sector de la opinión pública en una encuesta de 628 casos en la ciudad de Buenos Aires y la construcción de varios corpus discursivos periodísticos, sociales y de instituciones legales, entre otros, posibilitaron el análisis semiológico sobre distintas aristas y soportes, contribuyendo a un óptimo procesamiento de toda la información seleccionada, mostrando la creatividad en la construcción del objeto de estudio por parte de los autores.

En el capítulo "Armando el rompecabezas de la inseguridad: producción y circulación de la noticia policial en la televisión por aire", Valeria Bahl indaga el tratamiento de la noticia policial en los noticieros usando como caso de estudio las emisiones de Telenoche y Telenueve y las posibles relaciones entre la información televisiva y la difusión, y la reiteración de los repertorios de imágenes y sentidos sobre la necesidad de mayor control social. Asimismo, prácticas y representaciones estigmatizantes y violentas se unen desde diversos lugares enunciativos complejizando la mirada sobre el fenómeno y aportando elementos teóricos y reflexivos de un debate sensible dentro de la sociedad.

Pero el poliedro de visiones que componen la obra no se remite solamente a los medios audiovisuales, la prensa gráfica, internet y al estudio etnográfico, sino que abre interrogantes donde el espacio público es escenario de conflicto. Tal es el caso del trabajo titulado "Marginalidad, migraciones y violencias: la construcción mediática de la toma del parque Indoamericano", donde Naldi Crivelli y Lía Claps estudiaron la llamada "toma" de dicho predio que ocupó la agenda de los medios de comunicación en diciembre de 2010 con un alto grado de noticiabilidad y con estrategias discursivas que oscilaron entre la criminalización y el desconcierto ante ese hecho protagonizado por personas de bajos recursos. El estudio se piensa como "un signo ideológico" en 
términos de Volóshinov (1929) pues en él se "cruzan diferentes puntos de vista y criterios de evaluación".

Además, en el relevamiento y el análisis de los medios se pone énfasis en la centralidad de tales agendas de noticias sumando una persistencia de producir sentido sobre el crimen en el espacio público y en la impotencia del espacio privado que deja de serlo por el accionar delictivo. La herramienta estratégica de determinados medios es la reiteración ad infinitum de las crónicas del miedo y del padecimiento en la publicación diaria/secuencial, marca del relato unificado sobre la inseguridad.

La agenda del delito es tema y práctica constituyente del campo de la comunicación política pero además tiene una fuerte impronta en un determinado sector de la opinión pública. La reiteración espectacularizada de los casos más violentos apela a una conciencia "vecinal" (por lo grupal y compartido) e individual (por lo atemorizante de la soledad ante una amenaza) que produce efectos certeros sobre las formas de conciencias históricas, sociales y ciudadanas.

Reflexionar sobre la gestión del control social a través de las diversas expresiones de la opinión pública, las instituciones y los medios masivos, resulta un abordaje cuya originalidad ha permitido la búsqueda de discursos y prácticas trabajando sobre aspectos y fenómenos diversos, todos ellos marcados con acciones como la vigilancia, la represión o la estigmatización. La obra propone un recorrido por el sentido que se le da a la vida cotidiana implicada en un hábito del control, una lectura crítica de una realidad compleja y un fenómeno con aristas singulares y conflictivas.

\section{Juan Pablo Robledo}

Facultad de Ciencia Política y Relaciones Internacionales, Universidad Nacional de Rosario robledojuanpablo@gmail.com

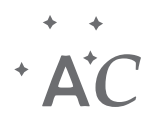

